\title{
Hard Ticks as Vectors Tested Negative for Severe Fever with Thrombocytopenia Syndrome in Ganghwa-do, Korea during 2019-2020
}

\author{
Kyoung Jin ${ }^{1, \dagger}$, Yeon-Ja Koh ${ }^{2, \dagger}$, Seong Kyu Ahn ${ }^{3, \#} \oplus$, Joonghee $\mathrm{Cho}^{2}$, Junghwan Lim², Jaeyong Song²,

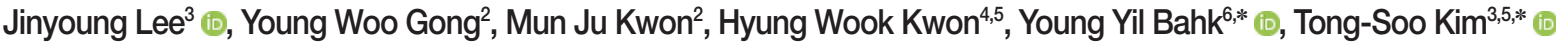 \\ ${ }^{1}$ Korea Health Evaluation Institute, Sahmyook University, Seoul 01795, Korea; ${ }^{2}$ Department of Infectious Diseases Diagnosis, Incheon Metropolitan \\ City Institute of Public Health and Environment, Incheon 22320, Korea; ${ }^{3}$ Department of Tropical Medicine \& Global Resource Bank of Parasitic \\ Protozoa Pathogens, Inha University School of Medicine, Incheon 22212, Korea; ${ }^{4}$ Department of Life Sciences, Incheon National University, \\ Incheon 22012, Korea; ${ }^{5}$ Convergence Research Center for Insect Vectors, Incheon National University, Incheon 22012, Korea; ${ }^{6}$ Department of \\ Biotechnology, College of Biomedical and Health Science, Konkuk University, Chungju 27478, Korea
}

\begin{abstract}
This study aimed to characterize the seasonal abundance of hard ticks that transmit severe fever with thrombocytopenia syndrome virus from April to November 2019 and 2020 on Ganghwa-do, Incheon Metropolitan City, Korea. The ticks were collected at grassland, grave site, copse and mountain road using a collection trap method. The ixodid hard ticks comprising three species (Haemaphysalis longicornis, H. flava, and Ixodes nipponensis) collected were 6,622 in 2019 and 3,811 in 2020. H. longicornis was the most frequent (97.9\% in 2019 and $96.0 \%$ in 2020), followed by $H$. flava (2.0\% and 3.0\% in 2019 and 2020, respectively) and $I$. nipponensis (less than $0.1 \%$ ). Our study demonstrated that seasonal patterns of the tick populations examined for two years were totally unsimilar. The hard ticks tested using RT-qPCR were all negative for severe fever with thrombocytopenia syndrome virus.
\end{abstract}

Key words: Monitoring, hard tick, SFTS, Ganghwa-do, Korea

\section{INTRODUCTION}

After the mosquitoes, the ticks are the second most common vectors. They damage directly the skin by biting and transmit a variety of pathogens to humans. The ticks are obligate blood-sucking ectoparasites of mammals, birds, and reptiles $[1,2]$. Ticks and their associated pathogens including bacteria, parasites, or viruses are among the most significant public health burdens worldwide. Their occurrence is known to expand, contract, and shift. Members of both the Argasidae (soft ticks) and Ixodidae (hard ticks) families are known to transmit viruses. The hard ticks are the primary vectors of viruses of medical and veterinary importance [3].

Severe fever with thrombocytopenia syndrome (SFTS) is a

- Received 22 April 2021, revised 26 May 2021, accepted 30 May 2021.

*Corresponding authors (bahk12@empal.com, byoung1@kku.ac.kr; tongsookim@ inha.ac.kr)

${ }^{\dagger}$ These authors contributed equally to this work.

\#Present address: Infectious Diseases Investigation Division, Jeonnam Institute of Public Health and Environment, Muan 58568, Korea.

(c) 2021, Korean Society for Parasitology and Tropical Medicine

This is an Open Access article distributed under the terms of the Creative Commons Attribution Non-Commercial License (https://creativecommons.org/licenses/by-nc/4.0) which permits unrestricted non-commercial use, distribution, and reproduction in any

medium, provided the original work is properly cited. emerging viral hemorrhagic fever and tick-borne infectious disease. The SFTS virus belongs to, newly characterized, genus Phlebovirus in family Bunyaviridae. STFS virus was first identified in the rural areas of Hubei and Henan provinces, China in 2009. SFTS is endemic in Korea and Japan as well as in China $[4,5]$. Among patients with a history of insect bites, SFTS is indistinguishable from other diseases such as tsutsugamushi, murine typhus, or anaplasmosis [6,7]. In Korea, the first SFTS patient was identified in 2012 [4]. Up to 2020, 1,330 SFTS patients were reported, thus this disease is recognized as a significant public health issue [8]. In Korea, the STFS occurrence was highest in October, followed by July and September. Of 17 provinces in Korea, Gyeonggi province had the largest number of patients (78 cases) of SFTS cases in 2019-2020, followed by Gangwon (59 cases) and Gyeongbuk (58 cases) provinces (Supplementary Fig. S1). In addition, depending on the recent cases of nosocomial infection in Korea, the possibility of transmission of SFTS caused by respiratory secretions could not be ruled out $[9,10]$. However, detailed transmission data for nosocomial infections of SFTS are limited in terms of attack rates and risk factors. This disease is nationally classified and managed as a group 3 infectious disease in Korea according to the 
Korean Act on the Prevention and Control of Infectious Diseases.

Ixodid hard ticks and Haemaphysalis longicornis are widespread in Korea and have been reported to be the main vectors of the pathogenic SFTS virus [11]. In order to establish strategies to control and prevent tick-borne diseases, it is pivotal to determine which species act as pathogen reservoirs, and which factors could promote the occurrence of hard tick vectors $[12,13]$.

Therefore, this study aimed to survey hard ticks on Ganghwa-do (Ganghwa County, Incheon Metropolitan City, Korea). Particularly, we characterized the species composition, diversity, abundance, and distribution of hard ticks and their pathogens to monitor and prevent the potential autochthonous transmission of tick-borne pathogens (e.g., especially SFTS virus), which may be related to the probable effects of climate change in Korea. The results of this study could provide the basis for future epidemiological studies and risk assessment of tick-borne pathogens in relation to climate change in Korea. The global environment is drastically and rapidly changing as a result of human activities, including population growth, urbanization, economic growth, natural resource use, energy production, and others. Notably, climate change has accelerated ecosystem changes, thereby influencing human life. Therefore, reliable monitoring data are needed to ensure timely warnings to safeguard public health. Our study could provide the basis for future epidemiological studies and risk assessment of increasing vector-borne pathogen occurrence associated with climate change in Korea.

\section{MATERIALS AND METHODS}

\section{Tick collection and sites}

Ganghwa-do is an island in Korea located in the Han River estuary. Specifically, this island is located in the Yellow Sea off Korea's west coast, separated from Gimpo on the South Korean mainland by a narrow channel spanned by two bridges and from Gaeseong City in North Korea by the main Han River channel. Ganghwa-do covers a $302.4 \mathrm{~km}^{2}$ area, measuring 28 $\mathrm{km}$ long and $22 \mathrm{~km}$ wide, making it the 4th largest island in Korea. The average yearly temperature and precipitation in this region are $16.2^{\circ} \mathrm{C}$ and $1,346 \mathrm{~mm}$, respectively. Ganghwa-do exhibits a humid continental climate (Dwa) [14].

Surveys of hard tick surveys were conducted in a grassland, a grave site, a copse, and a mountain road with the collection trap method from April to November of 2019 using three col- lection traps per site (i.e., 12 traps in total) on Ganghwa-do. The geographic indices (longitute/latitude) for each of the four surveillance sites are 37.733344/126.395645, 37.734496/ $126.397436,37.732803 / 126.398165$, and 37.733885/126.396880. Hard ticks were collected at each site on the same day to determine SFTS virus infection. Any specific permissions were not required for tick collection at these sites, since this study did not involve endangered species. The collected specimens were transported alive to a laboratory in the Department of Parasitology and Tropical Medicine, School of Medicine, Inha University. The hard ticks were identified to species level with taxonomic keys and classified according to their developmental stage based on morphological features $[15,16]$. However, larvae could not be classified to the species level due to difficulties in their identification.

\section{SFTS virus detection from hard ticks}

The collected hard ticks were pooled (pools of 1-5 adults and 1-30 larvae and nymphs) according to species, collection site, and collection time and quickly transferred to microcentrifuge tubes on ice. To improve and achieve maximal efficiency and reduce variability in the total RNA yields, the extraction was performed using bead beaters with $2.8 \mathrm{~mm}$ stainless steel beads (Precellys ${ }^{\mathrm{TM}}$ CK28-R Hard tissue homogenizing kit, Bertin Technologies, SAS, Montigny-le-Bretonneux, France) and TRIzolTM reagent (InVitrogen, Carlsbad, California, USA). The pooled hard ticks were homogenized in $500 \mu \mathrm{TRIzol}^{\mathrm{TM}} \mathrm{re}^{-}$ agent. After the hard tick homogenates were centrifuged at $15,000 \times \mathrm{g}$ for $10 \mathrm{~min}$, the supernatant was collected and RNA was extracted using the Direct Zol ${ }^{\mathrm{TM}} \mathrm{RNA}$ extraction kit (Zym Research, Irvine, California, USA) according to the manufacturer's protocol. The extracted total RNA was resuspended in RNase-free distilled water containing RNAsinTM Plus RNase inhibitor (Promega Co., Madison, Wisconsin, USA) and stored at $-80^{\circ} \mathrm{C}$ until further analysis. RT-qPCR assays were performed using the DiaStarTM 2x OneStep RT-PCR Pre-mix (SolGent Co., Daejeon, Korea) according to the manufacturer's protocol. The MF3 (forward) 5'GATGAAGATGG-TCCATGCTGATTCT-3 and MF2 (reverse) 5'-CTCATGGGGTGGAATGTCCTCAC-3' primers were used to detect the medium (M) segment of the SFTS virus $[11,17,18]$, whereas the actin L (forward) $5^{\prime}$-AGATC ATGTTCGAGACCTTC-3' and actin R (reverse) 5'-TCAGGAT CTTCATCAGGTAA- $3^{\prime}$ primers were used to identify $\beta$-actin. RTqPCR assays were carried out using $15 \mu \mathrm{l}$ of $2 \mathrm{x}$ OneStep RT-PCR Pre-mix, each with 10 pmole of primers, and $1 \mathrm{pg}$ to $100 \mathrm{ng}$ of 
total RNA in a $30 \mu \mathrm{l}$ total reaction volume. The RT-qPCR conditions for each reaction were as follows: $30 \mathrm{~min}$ at $50^{\circ} \mathrm{C}$, followed by $15 \mathrm{~min}$ at $95^{\circ} \mathrm{C}$, and $20 \mathrm{sec}$ at $95^{\circ} \mathrm{C}, 40 \mathrm{sec}$ at $58^{\circ} \mathrm{C}$ and $30 \mathrm{sec}$ at $72.5^{\circ} \mathrm{C}$ for 35 cycles, with a final annealing step for $10 \mathrm{~min}$ at $70^{\circ} \mathrm{C}$. Samples were determined to be positive for the SFTS virus if a virus-specific 560 bp DNA fragment band was observed after 1.3\% agarose gel electrophoresis stained with $0.1 \mu \mathrm{l} / \mathrm{ml} \mathrm{SYBR}^{\mathrm{TM}}$ Safe DNA Gel Stain (InVitrogen).

\section{RESULTS}

\section{Hard ticks collected}

The highest number of sampled specimens was obtained from short wild grass at the grassland site $[4,939 / 10,433$, $47.3 \%$ with a hard tick index (HTI; i.e., the total number of hard ticks divided by the total number of used traps) of 102.9 $(3,727 / 6,622,56.3 \%$, HTI of 155.3 in 2019; $1,212 / 3,811$, $31.8 \%$, HTI of 50.5 in 2020)], followed by the grave site [2,391/10,433, 22.9\%, HTI of $49.8(1,124 / 6,622,17.0 \%$, HTI of 4.6 .8 in 2019; $1,267 / 3,811,33.2 \%$, HTI of 52.8 in 2020)], the copse $[1,886 / 10,622,18.1 \%$, HTI of $39.3(1,033 / 6,622$, $15.6 \%$, HTI of 40.0 in 2019; 853/3,811, 22.4\%, HTI of 35.5 in $2020)]$, and the mountain road $[1,217 / 10,433,11.7 \%$, HTI of $25.4(738 / 6,622,11.1 \%$, HTI of 30.8 in 2019; 479/3,811, $12.6 \%$, HTI of 20.0)] (Table 1; Fig. 1A, B). A total of 10,433 ixodid hard ticks consisting of 3,206 larvae (30.7\%), 2,199 females (21.1\%), 1,039 males (10.1\%), and 3,989 nymphs (38.2\%) [3,167 larvae (47.8\%), 1,073 females (16.2\%), 441 males (6.7\%), and 1,941 nymphs (29.3\%) in 2019; 39 larvae $(1.0 \%), 1,126$ females $(29.5 \%), 598$ males $(15.7 \%)$, and 2,048 nymphs (53.7\%) in 2020] comprising three species ( $H$. longicornis, $H$. flava, and Ixodes nipponensis) were collected from four sites (grassland, grave site, copse, and mountain road) using collection traps from April to November during 2019-2020 in Ganghwa-do (Supplementary Tables S1, S2). The collection months with the highest number of sampled hard ticks from the grassland were August in 2019 and May in 2020; however, the number of specimens was comparable from September to November among the collection sites (Fig. 1A, B). Given the similar temperature and relative humidity throughout the island, hard tick density was mainly affected by inter-site differences. Based on the results, short wild grass was a more favorable habitat than the copse environment. Although the grave site was covered with grass, the density of hard ticks at this site was relatively low compared with that at the grassland; this was expected considering that grave sites are generally sprayed with artificial insect or tick repellents. Of the taxonomically identified hard ticks, H. longicornis, a widespread species in Korea, was the most frequently collected specimen excluding larval ticks (7,352/7,540 including nymphs and adults, 97.5\%), followed by $H$. flava $(182 / 7,540,2.4 \%)$ and I. nipponensis $(6 / 7,540$, less than $0.1 \%)$ (Supplementary Tables S1, S2). Moreover, all three species collected in this survey were found to bite humans, as reported in other studies [19]. H. longicornis is a known mammal ectoparasite, whereas $H$. flava is a bird and mammal parasite [20]. However, the density of I. nipponensis, was too low for this species to be considered as a relevant SFTS vector at our surveillance sites. The collection traps were set at each of the collection site as well as our previous surveillance studies from 2015 to 2018 [11,17,18,21,22]: the grassland (37.733344/126.395645), the grave site (37.734496/ $126.397436)$, the copse $(37.732803 / 126.398165)$ and the mountain road (37.733885/126.396880). This study collected a total of 2,199 female hard ticks (21.1\%), 1,039 male hard ticks (10.0\%), 3,989 nymphs (38.2\%), and 3,206 larvae (30.7\%) (Supplementary Tables S1, S2) in 2019-2020; the results are consistent with the expected ratio of larvae, nymphs, and adults. In general, H. longicornis population densities started to increase in May, peaked in June and decreased rapidly thereafter (Fig. 2). In addition, H. flava population densities appeared to peak in September; however, sample sizes were too low to be representative of the general population density. The population densities of larvae showed a bimodal trend in 2019, with the highest number of specimens collected in August, followed by the second highest number in October (Fig. 3A). However, in 2020, the collected number of hard ticks in this study was greatly reduced in August, which, may be attributed to frequent typhoons in the Ganghwa-do region (Fig. 3B). This climate phenomenon seems to have had a large effect on the distribution of hard ticks in this study.

\section{STFS virus and hard ticks}

All of the examined hard tick pools tested (327 in 2019, 263 in 2020, Table 2) was negative for the SFTS virus (560 bp DNA fragment of the viral M segment) $[11,17,18]$.

\section{DISCUSSION}

Climate change effects have accelerated in Korea since its rapid urban and industrial development from the 1960s to 
Table 1. Collection rate and hard tick indices in Ganghwa-do, 2019-2020

\begin{tabular}{|c|c|c|c|c|c|c|c|c|c|}
\hline \multirow{2}{*}{ Collection site } & \multirow{2}{*}{$\begin{array}{l}\text { Collection } \\
\text { month }\end{array}$} & \multicolumn{2}{|c|}{ No. of collection traps } & \multicolumn{3}{|c|}{ No. of collected hard ticks } & \multicolumn{3}{|c|}{ Hard tick index } \\
\hline & & 2019 & 2020 & 2019 & 2020 & Subtotal & 2019 & 2020 & Subtotal \\
\hline \multirow[t]{9}{*}{ Grassland } & April & 3 & 3 & 261 & 46 & 307 & 87.0 & 15.3 & 51.2 \\
\hline & May & 3 & 3 & 553 & 641 & 1,194 & 184.3 & 213.7 & 199.0 \\
\hline & June & 3 & 3 & 368 & 485 & 853 & 122.7 & 161.7 & 142.2 \\
\hline & July & 3 & 3 & 102 & 22 & 124 & 34.0 & 7.3 & 20.7 \\
\hline & August & 3 & 3 & 2,086 & 3 & 2,089 & 695.3 & 1.0 & 348.2 \\
\hline & September & 3 & 3 & 118 & 15 & 133 & 39.3 & 5.0 & 22.2 \\
\hline & October & 3 & 3 & 239 & 0 & 239 & 79.7 & 0 & 39.8 \\
\hline & November & 3 & 3 & 0 & 0 & 0 & 0 & 0 & 0 \\
\hline & Subtotal & 24 & 24 & 3,727 & 1,212 & 4,939 & 155.3 & 50.5 & 102.9 \\
\hline \multirow[t]{9}{*}{ Grave } & April & 3 & 3 & 33 & 146 & 179 & 11.0 & 48.7 & 29.8 \\
\hline & May & 3 & 3 & 153 & 739 & 892 & 51.0 & 246.3 & 148.7 \\
\hline & June & 3 & 3 & 387 & 219 & 606 & 129.0 & 73.0 & 36.5 \\
\hline & July & 3 & 3 & 181 & 66 & 247 & 60.3 & 22.0 & 41.2 \\
\hline & August & 3 & 3 & 194 & 24 & 218 & 64.7 & 8.0 & 36.3 \\
\hline & September & 3 & 3 & 126 & 52 & 178 & 42.0 & 17.3 & 29.7 \\
\hline & October & 3 & 3 & 48 & 20 & 68 & 16.0 & 6.7 & 11.3 \\
\hline & November & 3 & 3 & 2 & 1 & 3 & 0.7 & 1.3 & 0.5 \\
\hline & Subtotal & 24 & 24 & 1,124 & 1,267 & 2,391 & 46.8 & 52.8 & 49.8 \\
\hline \multirow{9}{*}{ Copse } & April & 3 & 3 & 163 & 27 & 190 & 54.3 & 9.0 & 31.7 \\
\hline & May & 3 & 3 & 37 & 400 & 437 & 2.3 & 133.3 & 72.8 \\
\hline & June & 3 & 3 & 332 & 99 & 431 & 110.7 & 33.0 & 71.8 \\
\hline & July & 3 & 3 & 242 & 272 & 514 & 80.7 & 90.7 & 85.7 \\
\hline & August & 3 & 3 & 240 & 16 & 256 & 80.0 & 5.3 & 42.7 \\
\hline & September & 3 & 3 & 10 & 29 & 39 & 3.3 & 9.7 & 6.5 \\
\hline & October & 3 & 3 & 9 & 4 & 13 & 3.0 & 1.3 & 7.8 \\
\hline & November & 3 & 3 & 0 & 6 & 6 & 0 & 2.0 & 1.0 \\
\hline & Subtotal & 24 & 24 & 1,033 & 853 & 1,886 & 40.0 & 35.5 & 39.3 \\
\hline \multirow[t]{9}{*}{ Mountain road } & April & 3 & 3 & 167 & 27 & 194 & 55.7 & 9.0 & 32.3 \\
\hline & May & 3 & 3 & 131 & 128 & 159 & 43.7 & 42.7 & 26.5 \\
\hline & June & 3 & 3 & 213 & 162 & 375 & 71.0 & 54.0 & 62.5 \\
\hline & July & 3 & 3 & 124 & 132 & 256 & 41.3 & 44.0 & 42.7 \\
\hline & August & 3 & 3 & 38 & 8 & 46 & 12.7 & 2.7 & 7.7 \\
\hline & September & 3 & 3 & 26 & 19 & 45 & 8.7 & 6.3 & 7.5 \\
\hline & October & 3 & 3 & 39 & 3 & 42 & 13.0 & 1.0 & 7.0 \\
\hline & November & 3 & 3 & 0 & 0 & 0 & 0 & 0 & 0 \\
\hline & Subtotal & 24 & 24 & 738 & 479 & 1,217 & 30.8 & 20.0 & 25.4 \\
\hline Total & & 96 & 96 & 6,622 & 3,811 & 10,433 & 69.0 & 39.7 & 54.3 \\
\hline
\end{tabular}

A

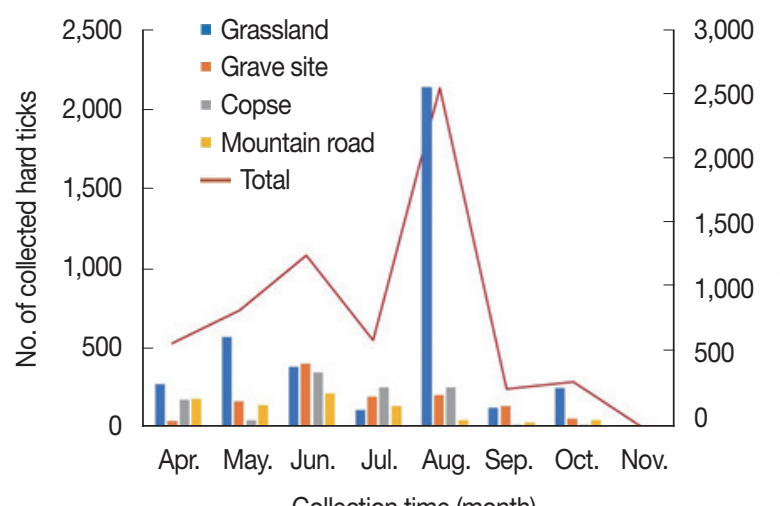

B

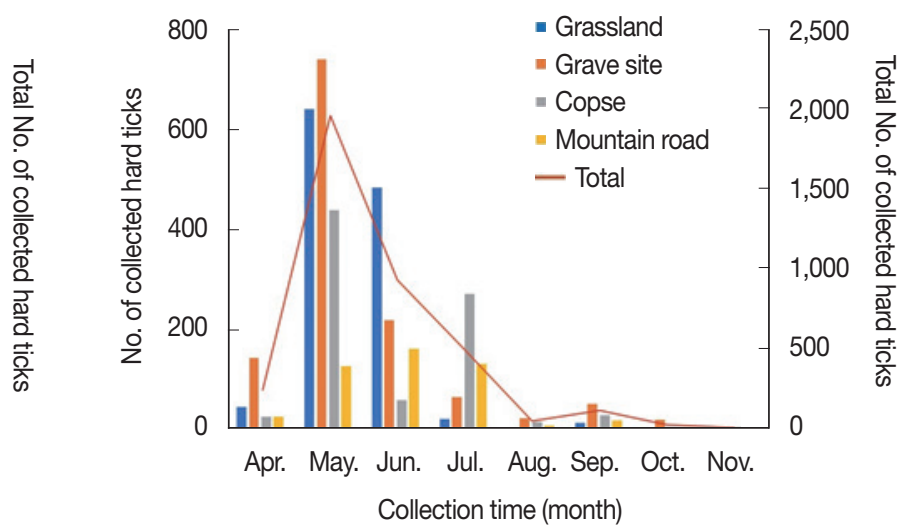

Fig. 1. Distribution of the collected hard tick density at each collection site from April to November. (A) 2019. (B) 2020. 
1990s [23]. Rapid increases in population and industrialization have accelerated the emission of various pollutants and greenhouse gases, which are major anthropogenic factors. Korea has been largely affected by climate parameters, including

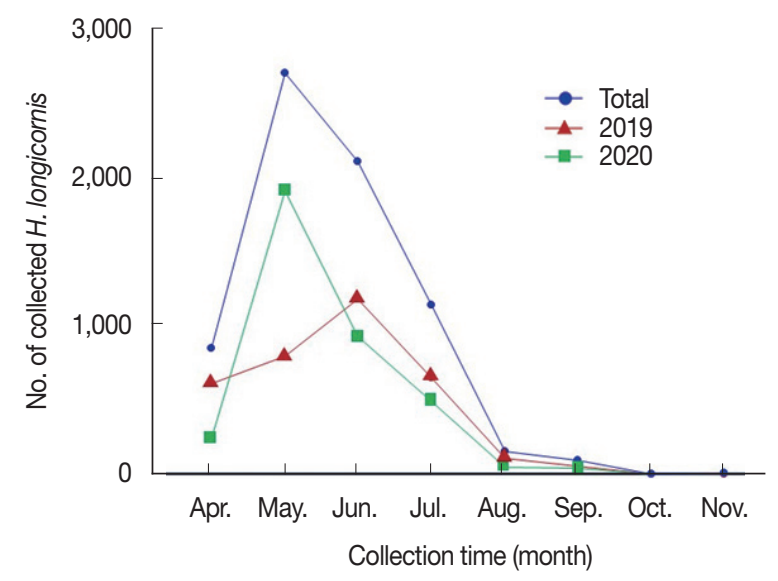

Fig. 2. Monthly distribution of a hard tick, Haemaphysalis longicornis in 2019 and 2020.

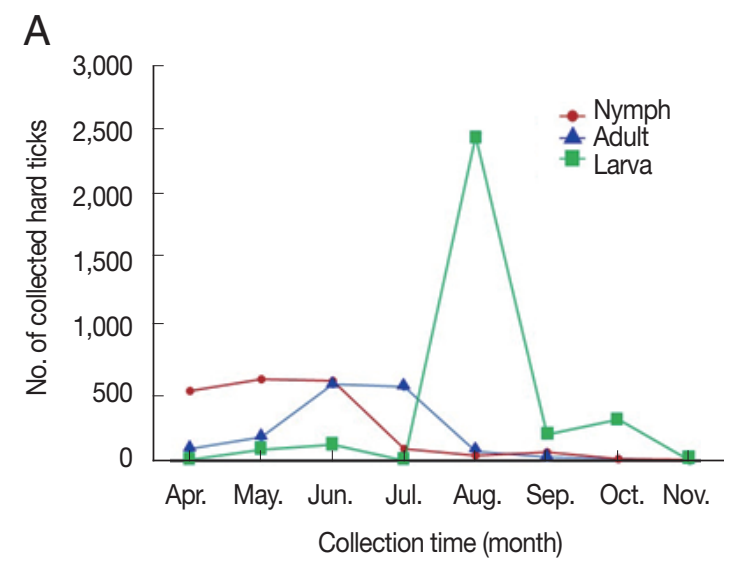

temperature and precipitation [24]. The most distinct climate change in Korea is an increase in temperature fluctuations throughout the four seasons. The number of record minimum temperature days has greatly decreased, and the maximum precipitation during the summer season has increased. Ongoing worldwide climate change has contributed to nationwide climate change effects and extreme weather events [25]. Notably, hard tick populations are closely associated with climate change, as their survival largely depends on environmental factors.

Ixodid ticks belong to 4 species from two genera: $H$. longicornis, H. flava, I. nipponensis, and I. pesulcatus [22]. The SFTS virus has previously been identified in ticks belonging to three genera and four species (H. longicornis, H. flava, I. nipponensis, and Amblyomma testudinarium) [26]. Recently, the SFTS virus has been identified in all $H$. longicornis developmental stages (eggs, adults, nymphs, and larvae) in China [27]. In Korea, $H$. longicornis is the most identified and reported hard tick species, and almost all hard tick-borne diseases in Korea have been at-

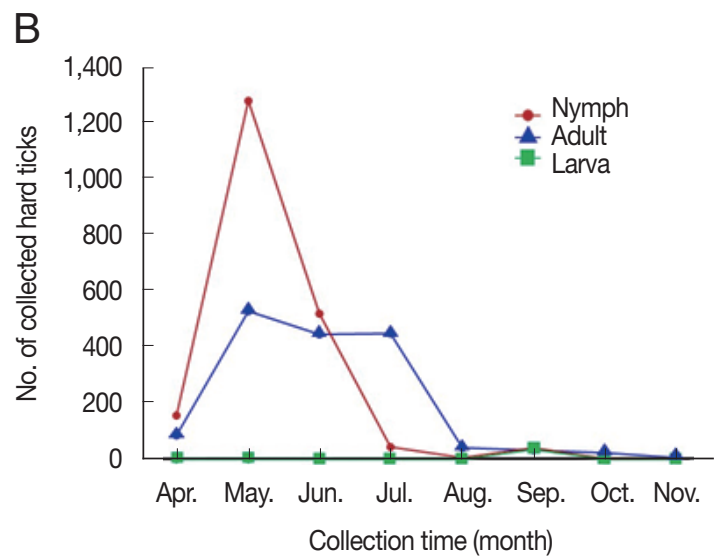

Fig. 3. Monthly distribution of the developmental hard ticks by (adult, nymph and larva). (A) 2019. (B) 2020.

Table 2. Collection and pools of hard ticks tested for SFTS virus in 2019 and 2020

\begin{tabular}{|c|c|c|c|c|c|c|c|c|c|c|}
\hline \multirow{2}{*}{ Collection site } & \multirow{2}{*}{$\begin{array}{l}\text { Collection } \\
\text { month }\end{array}$} & \multicolumn{3}{|c|}{ No. of collected hard ticks } & \multicolumn{3}{|c|}{ No. of analyzed hard ticks ${ }^{a}$} & \multicolumn{3}{|c|}{ No. of pools } \\
\hline & & 2019 & 2020 & Total & 2019 & 2020 & Total & 2019 & 2020 & Total \\
\hline \multirow[t]{8}{*}{ Ganghwa Island } & April & 624 & 246 & 870 & 303 & 127 & 430 & 32 & 20 & 52 \\
\hline & May & 874 & 1,908 & 2,782 & 434 & 958 & 1,392 & 37 & 89 & 126 \\
\hline & June & 1,300 & 965 & 2,265 & 646 & 485 & 1,131 & 79 & 57 & 136 \\
\hline & July & 649 & 492 & 1,141 & 320 & 250 & 570 & 65 & 51 & 116 \\
\hline & August & 2,558 & 51 & 2,609 & 1,275 & 30 & 1,305 & 78 & 16 & 94 \\
\hline & September & 280 & 115 & 395 & 135 & 62 & 197 & 19 & 20 & 39 \\
\hline & October & 335 & 27 & 362 & 163 & 160 & 323 & 16 & 7 & 23 \\
\hline & November & 2 & 7 & 9 & 1 & 7 & 8 & 1 & 3 & 4 \\
\hline Total & & 6,622 & 3,811 & 10,433 & 3,277 & 2,079 & 5,356 & 327 & 263 & 590 \\
\hline
\end{tabular}

aln this surveillance, all of the tested pools were negative for SFTS virus. 
tributed to this species $[15,26,28,29]$. A. testudinarium and $I$. nipponensis may also act as additional vectors of the SFTS virus in Korea [11]. In this study, we demonstrated that H. longicornis was widely distributed on Ganghwa-do as the dominant hard tick species (97.89\% with the collection trap method) and that it did not carry the SFTS virus in the studied locations. However, the number of specimens was small for $H$. flava and I. nipponensis [182/7,540 (2.4\%) and 6/7,540 (0.1\%), respectively], compared with $H$. longicornis; thus, an accurate judgment could not be made on whether these species were disease carriers. These results are consistent with those of our previous 4-year surveillance study (from 2015 to 2018) in the same locations [18]. Moreover, there might be other tick species in addition to those identified at the study sites [30]. Previously, it was reported that $H$. longicornis was the most frequently collected hard ticks in northern Gyeonggi province $(75.8 \%)$ [31], as well as in the southern province and Jeju Island (73.4\%) [32]. However, in contrast to our results, H. flava and I. nipponensis accounted for $19.6 \%$ and $4.6 \%$ in northern Gyeonggi province and $22.4 \%$ and $0.4 \%$ of the collected hard ticks, respectively, in the southern province. In 2020, the collected number of hard ticks in this study dramatically reduced in August, which may be attributed to frequent typhoons in the Ganghwa-do region. This climate phenomenon seems to have had a huge effect on the distribution of the collection of hard ticks in this study.

In Taiwan, the RNA and antibodies of the SFTS virus have been detected in $20.5 \%, 37.7 \%$, and $41.7 \%$ of the sheep, dog, and bovine samples that were analyzed, indicating the presence of the SFTS virus in Taiwan [33]. In addition, based on the detection of SFTS virus-specific antibodies by ELISA, 3.6\% and $47.4 \%$ of human and animal serum samples, respectively, were positive for SFTS virus antibodies, indicating that the SFTS virus is distributed widely among domestic animals and birds, as well as wild animals in China [34-36]. However, the whole cohort did not show any specific clinical signs of illness, and all of the animals survived infection. These results suggest that domestic animals and wild animals may be reservoir animal hosts during SFTS virus amplification in the endemic area. Thus far, our country has not actively examined antibodies and RNA in SFTS tests for domestic animals; however, at this rate, it may be desirable to perform tests for antibody or RNA detection in these animals in the future.

Our survey could provide a useful mean to promote awareness of STFS occurrence to establish public health guideline accordingly. Since STFS began to be managed as a state-recognized epidemic in 2013, 1,330 STFS cases including 6 suspected cases have been reported by 2020 [8]. Between 2013 and 2020 , an average of 166.3 people became infected with this virus in Korea and there is an increasing trend in infections (36 cases in 2013, 55 cases in 2014, 79 cases in 2015, 165 cases in 2016, 272 cases in 2017, 259 cases in 2018, 223 cases in 2019, and 241 cases in 2020). SFTS is a prevalent endemic disease in Korea with a high fatality ratio. The fatality rates of this disease were reported by the Korea Disease Control and Prevention Agency as 7.2\% in 2013 [37] and 32.6\% from 2013 to 2015 [38]. SFTS occurs throughout Korea; the occurrence rate is relatively high in mountainous and hilly areas, such as Gangwon, northern Gyeonggi and Jeju Island, and relatively low in the western and southwestern plains. Nevertheless, the SFTS outbreak incidence has been increasing every year [39]. The prevalence of the SFTS virus in hard ticks collected from vegetation in Korea is around $0-0.46 \%[11,40,41]$. A study on the prevalence of the SFTS virus in five Korean National Parks demonstrated that the infection rate of this virus in adult and nymph hard ticks was 3.61\% and that in larval hard ticks was $0.31 \%$ [42]. In general, several factors may contribute to SFTS occurrence, including climate change, outdoor activities, hard tick population levels, and hard tick developmental stages. Different hard tick collection methods have yielded complementary information on the hard ticks at different sites according to vegetation and collection time, thereby reflecting the habitat preference and biology of the studied hard ticks. In this study, none of the examined pools tested positive for the SFTS virus after RT-qPCR analysis (Table 2). The prevalence of target pathogens is among the most important information in the study of hard tick and tick-borne parasite epidemiology. Moreover, the role of hard ticks as vectors and infection prevalence are important considerations for the development of adequate hard tick control strategies, especially in the context of climate change. The results of our small-scale study were comparable with those of a previous study, in which the hard ticks were collected by the same researchers over the 6-year period (20152020) [15]. Our study demonstrated that the seasonal patterns determined using the collection trap method were largely similar, and an overall slight decrease in the collected ticks was observed.

SFTS is a prevalent endemic hard-tick-borne disease in Korea with steadily increasing fatality and incidence rates over the past years. In conclusion of this study, none of the collected 
hard tick pools tested positive for SFTS. Nevertheless, this study provides an important methodological basis for the detection of the SFTS virus in tick vectors using Ganghwa-do as a case study, which is important for a more comprehensive characterization of the disease. The results could facilitate the establishment of more effective STFS control and prevention strategies. Additionally, our long-term survey provides baseline data for future studies to further investigate changes in hard tick composition, abundance, and distribution in response to future environmental conditions. A better understanding of the potential impact of climate change and vector ecology is critical for understanding the epidemiology of infectious diseases, including SFTS and their potential burden on public health. Therefore, future studies should examine the spread of vector-borne diseases and long-term surveillance data on infectious disease pathogens and vectors to effectively address their associated public health effects.

\section{ACKNOWLEDGMENT}

This study was supported by the Korea Disease Control and Prevention Agency (4851-304-320), the Priority Research Centers Program through the National Research Foundation funded by the Ministry of Education (2020R1A6A1A03041954) and the Inha University Research Fund (65321-1) in Korea.

\section{CONFLICT OF INTEREST}

The authors declare that there is no conflict of interest regarding the publication of this article.

\section{REFERENCES}

1. de la Fuente J, Estrada-Pena A, Venzal JM, Kocan KM, Sonenshine DE. Overview: ticks as vectors of pathogens that cause disease in humans and animals. Front Biosci 2008; 13: 6938-6946. https://doi.org/10.2741/3200

2. Mansfield KL, Jizhou Lv, Phipps LP, Johnson N. Emerging tickborne viruses in the twenty-first century. Front Cell Infect Microbiol 2017; 7: 298. https://doi.org/10.3389/fcimb.2017.00298

3. Sonenshine DE, Roe RM. Biology of Ticks, Vol. 2. Oxford University Press. Oxford, UK. 2013, pp180-210. https://global.oup.com/ academic/product/biology-of-ticks-volume-2-9780199744060? $\mathrm{cc}=\mathrm{kr} \& \mathrm{lang}=\mathrm{en} \&$

4. Kim KH, Yi J, Kim G, Choi SJ, Jun KI, Kim NH, Choe PG, Kim NJ, Lee JK, Oh MD. Severe fever with thrombocytopenia syndrome, South Korea, 2012. Emerg Infect Dis 2013; 19: 1892-
1894. https://doi.org/10.3201/eid1911.130792

5. Takahashi T, Maeda K, Suzuki T, Ishido A, Shigeoka T, Tominaga T, Kamei T, Honda M, Ninomiya D, Sakai T, Senba T, Kaneyuki S, Sakaguchi S, Satoh A, Hosokawa T, Kawabe Y, Kurihara S, Izumikawa K, Kohno S, Azuma T, Suemori K, Yasukawa M, Mizutani T, Omatsu T, Katayama Y, Miyahara M, Ijuin M, Doi K, Okuda M, Umeki K, Saito T, Fukushima K, Nakajima K, Yoshikawa T, Tani H, Fukushi S, Fukuma A, Ogata M, Shimojima M, Nakajima N, Nagata N, Katano H, Fukumoto H, Sato Y, Hasegawa H, Yamagishi T, Oishi K, Kurane I, Morikawa S, Saijo M. The first identification and retrospective study of Severe Fever with Thrombocytopenia Syndrome in Japan. J Infect Dis 2014; 209: 816-827. https://doi.org/10.1093/infdis/jit603

6. Gai ZT, Zhang Y, Liang MF, Jin C, Zhang S, Zhu CB, Li C, Li XY, Zhang QF, Bian PF, Zhang LH, Wang B, Zhou N, Liu JX, Song XG, Xu A, Bi ZQ, Chen SJ, Li DX. Clinical progress and risk factors for death in severe fever with thrombocytopenia syndrome patients. J Infect Dis 2012; 206: 1095-1102. https://doi.org/10.1093/infdis/ jis472

7. Park SW, Lee CS, Kim JH, Bae IG, Moon C, Kwak YG, Kim BN, Lee JH, Ryu SY, Jang HC, Hur J, Jun JB, Jung Y, Chang HH, Kim YK, Hwang JH, Kim YS, Jeong HW, Song KH, Park WB, Kim ES, Oh MD. Severe fever with thrombocytopenia syndrome: comparison with scrub typhus and clinical diagnostic prediction. BMC Infect Dis 2019; 19: 174. https://doi.org/10.1186/s12879019-3773-1.

8. Korean Centers for Disease Control and Prevention. Disease Web Statistics System [Internet]. Available from: http://is.kdca. go.kr/dstar/jsp/stat/stat0001.jsp

9. Kim WY, Choi W, Park SW, Wang EB, Lee WJ, Jee Y, Lim KS, Lee HJ, Kim SM, Lee SO, Choi SH, Kim YS, Woo JH, Kim SH. Nosocomial transmission of severe fever with thrombocytopenia syndrome in Korea. Clin Infect Dis 2015; 60: 1681-1683. https:// doi.org/10.1093/cid/civ128

10. Jeong EJ, Song JY, Lim CS, Lee I, Park MS, Choi MJ, Jeon JH, Kang SH, Jung BK, Yoon JG, Hyun HJ, Noh JY, Cheong HJ, Kim WJ. Viral shedding from diverse body fluids in a patient with severe fever with thrombocytopenia syndrome. J Clin Virol 2016; 80: 33-35. http://dx.doi.org/10.1016/j.jcv.2016.04.018

11. Yun SM, Lee WG, Ryou J, Yang SC, Park SW, Roh JY, Lee YJ, Park C, Han MG. Severe fever with thrombocytopenia syndrome virus in ticks collected from humans, South Korea. 2013. Emerg Infect Dis 2014; 20: 1358-1361. https://doi.org/10.3201/eid2008.131857.

12. Dobson ADM, Taylor JL, Randolph SE. Tick (Ixodes ricinus) abundance and seasonality at recreational sites in the UK: hazards in relation to fine-scale habitat types revealed by complementary sampling methods. Ticks Tick Borne Dis 2011; 2: 67-74. https://doi.org/10.1016/j.ttbdis.2011.03.002

13. Domínguez L, Miranda RJ, Torres S, Moreno R, Ortega J, Bermúdez SE. Hard tick (Acari: Ixodidae) survey of Oleoducto trail, Soberania National Park, Panama. Ticks Tick Borne Dis 2019; 10: 830-837. https://doi.org/10.1016/j.ttbdis.2019.04.001

14. Kottek M, Grieser J, Beck C, Rudolf B, Rubel F. World map of the Köp- 
pen-Geiger climate classification updated. Meteorologische Zeitschrift 2006; 15: 259-263. https://doi.org/10.1127/0941-2948/2006/0130

15. Yamaguti N, Tipton VJ, Keegan HL, Toshioka S. Ticks of Japan, Korea, and the Ryukyu Islands. Vol. 15. Brigham Young University. Provo, USA. pp 1-227. https://scholarsarchive.byu.edu/cgi/ viewcontent.cgi?article $=1066$ \& context=byuscib

16. Azad AF. Mites of Public Health Importance and Their Control. Vector Biology and Control Division, World Health Organization. 1986, pp 1-52. https://apps.who.int/iris/handle/10665/58177

17. Yun SM, Lee YJ, Choi W, Kim HC, Chong ST, Chang KS, Coburn JM, Klein TA, Lee WJ. Molecular detection of severe fever with thrombocytopenia syndrome and tick-borne encephalitis viruses in ixodid ticks collected from vegetation, Republic of Korea, 2014. Ticks Tick Borne Dis 2016; 7: 970-978. https://doi.org/ 10.1016/j.ttbdis.2016.05.003

18. Kim-Jeon MD, Jegal S, Jun H, Jung H, Park SH, Ahn SK, Lee J, Gong YW, Joo K, Kwon MJ, Roh JY, Lee WG, Bahk YY, Kim TS. Four-year surveillance of the vector hard ticks for SFTS Ganghwado, Republic of Korea. Korean J Parasitol 2019; 57: 691-698. https://doi.org/10.3347/kjp.2019.57.6.691

19. Shin J, Park J, Kwon D. Epidemiologic and clinical characteristics of severe fever with thrombocytopenia syndrome in the Republic of Korea. Publ Health Weekly Rep 2014; 7: 493-498. https:// www.researchgate.net/publication/285716160

20. Lee WT, Lim JW, Lee SY, Lee IY. Redistribution of Haemaphysalis flava and Ixodes tanuki collected from raccoon dog in Korea. Korean J Parasitol 1997; 35: 1-8 (in Korean). https://doi.org/10. 3347/kjp.1997.35.1.1

21. Jo YS, Kang JG, Chae JB, Cho YK, Shin JH, Jheong WH, Chae JS. Prevalence of severe fever with thrombocytopenia syndrome virus in Haemaphysalis longicornis ticks in Seoul, Korea. Ticks Tick Borne Dis 2014; 5: 975-977. https://doi.org/10.1016/j.ttbdis.2014.07.020

22. Yun SM, Song BG, Choi W, Park WI, Kim SY, Roh JY, Ryou J, Ju YR, Park C, Shin EH. Prevalence of tick-borne encephalitis virus in Ixodid ticks collected from the Republic of Korea during 20112012. Osong Public Health Res Perspect 2012; 3: 213-221. https:// doi.org/10.1016/j.phrp.2012.10.004

23. Kleiner J. Korea, a Century of Change. World Scientific. New Jersey, USA. https://books.google.co.kr/books?id=nTCC2ZheFu0C \&printsec=frontcover\&hl=ko\&source=gbs_ge summary_r\&cad= $0 \# \mathrm{v}=$ onepage \& $\mathrm{q} \& \mathrm{f}=\mathrm{false}$

24. Chung YS, Yoon MB, Kim HS. On climate variations and changes observed in South Korea. Climate Change 2004; 66: 151-161. https://doi.org/10.1023/B:CLIM.0000043141.54763.f8

25. Kim BJ, Kripalani RH, Oh J-H, Moon SE. Summer monsoon rainfall patterns over South Korea and associated circulation features. Theor Appl Climatol 2002; 72: 65-74. https://doi.org/10.1007/ s007040200013

26. Yun SM, Song BG, Choi W, Roh JY, Lee YJ, Park WI, Han MG, Ju YR, Lee WJ. First isolation of severe fever with thrombocytopenia syndrome virus from Haemaphysalis longicornis ticks collected in severe fever with thrombocytopenia syndrome outbreak areas in the Republic of Korea. Vector Borne Zoonotic Dis 2016; 16: 66-
70. https://doi.org/10.1089/vbz.2015.1832

27. Wang S, Li J, Niu G, Wang X, Ding S, Jiang X, Li C, Zhang Q, Liang M, Bi Z, Li D. STFS virus in ticks in an endemic area of China. Am J Trop Med Hyg 2015; 92: 684-689. https://doi.org/10.4269/ajtmh. 14-0008

28. Chae JB, Kang JG, Kim HC, Chong ST, Lee IY, Shin NS, Chae JS. Identification of tick species collected from wild boars and habitats of wild boars and domestic pigs in the Republic of Korea. Korean J Parasitol 2017; 55: 185-191. https://doi.org/10.3347/kjp. 2017.55.2.185

29. Chae JB, Cho YS, Cho YK, Kang JG, Shin NS, Chae JS. Epidemiological investigation of tick species from near domestic animal farms and cattle goat, and wild boar in Korea. Korean J Parasitol 2019; 57: 319-324. https://doi.org/10.3347/kjp.2019.57.3.319

30. Chong ST, Kim HC, Lee IY, Kollars TM Jr, Sancho AR, Sames WJ, Klein TA. Comparison of dragging and sweeping methods for collecting ticks and determining their seasonal distributions for various habitats, Gyeonggi Province, Republic of Korea. J Med Entomol 2013; 50: 611-618. https://doi.org/10.1603/me12032

31. Chong ST, Kim HC, Lee IY, Kollars TM Jr, Sancho AR, Sames WJ, Chae JS, Klein TA. Seasonal distribution of ticks in four habitats near the demilitarized zone, Gyeonggi-do (province), Republic of Korea. Korean J Parasitol 2013; 51: 319-325. https://doi.org/10.3347/ kjp.2013.51.3.319

32. Ko S, Kang JG, Kim SY, Kim HC, Klein TA, Chong ST, Sames WJ, Yun SM, Ju YR, Chae JS. Prevalence of tick-borne encephalitis virus in ticks from southern Korea. J Vet Sci 2010; 11: 197-203. https:// doi.org/10.4142/jvs.2010.11.3.197

33. Lin TL, Ou SC, Maeda K, Shimoda H, Chan JP, Tu WC, Hsu WL, Chou CC. The first discovery of severe fever with thrombocytopenia syndrome virus in Taiwan. Emerg Microbes Infect 2020; 9: 148-151. https://doi.org/10.1080/22221751.2019.1710436

34. Jiao Y, Zeng X, Guo X, Qi X, Zhang X, Shi Z, Zhou M, Bao C, Zhang W, Xu Y, Wang H. Preparation and evaluation of recombinant severe fever with thrombocytopenia syndrome virus nucleocapsid protein for detection of total antibodies in human and animal sera by double-antigen sandwich enzyme-linked immunosorbent assay. J Clin Microbiol 2012; 50: 372-377. https:// doi.org/10.1128/JCM.01319-11

35. Zhang X, Liu Y, Zhao L, Li B, Yu H, Wen H, Yu XJ. An emerging hemorrhagic fever in China caused by a novel bunyavirus SFTSV. Sci China Life Sci 2013; 56: 697-700. https://doi.org/10.1007/ s11427-013-4518-9

36. Huang XY, Du YH, Wang HF, You AG, Li Y, Su J, Nie YF, Ma HX, $\mathrm{Xu}$ BL. Prevalence of severe fever with thrombocytopenia syndrome virus in animals in Henan Province, China. Infect Dis Poverty 2019; 8: 56. https://doi.org/10.1186/s40249-019-0569-x

37. Park SW, Han MG, Yun SM, Park C, Lee WJ, Ryou J. Severe fever with thrombocytopenia syndrome virus, South Korea, 2013. Emerg Infect Dis 2014; 20: 1880-1882. https://doi.org/10.3201/ eid2011.140888

38. Choi SJ, Park SW, Bae IG, Kim SH, Ryu SY, Kim HA, Jang HC, Hur J, Jun JB, Jung Y, Chang HH, Kim YK, Yi J, Kim KH, Hwang 
JH, Kim YS, Jeong HW, Song KH, Park WB, Kim ES, Oh MD. Severe fever with thrombocytopenia syndrome in South Korea, 2013-2015. PLoS Negl Trop Dis 2016; 10: e0005264. https://doi. org/10.1371/journal.pntd.0005264

39. Im JH, Baek J, Durey A, Kwon HY, Chung MH, Lee JS. Current status of tick-borne diseases in South Korea. Vector Borne Zoonotic Dis 2019; 19: 225-233. https://doi.org/10.1089/vbz.2018.2298

40. Park SW, Song BG, Shin EH, Yun SM, Han MG, Park MY, Park C, Ryou J. Prevalence of severe fever with thrombocytopenia syndrome virus in Haemaphysalis longicornis ticks in South Korea.
Ticks Tick Borne Dis 2014; 5: 975-977. https://doi.org/10.1016/ j.ttbdis.2014.07.020

41. Ham H, Jo S, Jang J, Choi S. No detection of severe fever with thrombocytopenia syndrome virus from Ixodid ticks collected in Seoul. Korean J Parasitol 2014; 52: 221-224. https://doi.org/10.3347/ kjp.2014.52.2.221

42. Jo YS, Kang JG, Chae JB, Cho YK, Shin JH, Jheong WH, Chae JS. Prevalence of severe fever with thrombocytopenia syndrome virus in ticks collected from national parks in Korea. Vector Borne Zoonotic Dis 2019; 19: 284-289. https://doi.org/10.1089/vbz.2018.2338. 
